\title{
Derek Allan, Art and the Human Adventure. André Malraux's Theory of Art
}

\section{Riccardo Benedettini}

\section{Q OpenEdition \\ 1 Journals}

\section{Edizione digitale}

URL: http://journals.openedition.org/studifrancesi/6426

DOI: 10.4000/studifrancesi.6426

ISSN: 2421-5856

\section{Editore}

Rosenberg \& Sellier

\section{Edizione cartacea}

Data di pubblicazione: 1 novembre 2010

Paginazione: 587-588

ISSN: 0039-2944

\section{Notizia bibliografica digitale}

Riccardo Benedettini, «Derek Allan, Art and the Human Adventure. André Malraux's Theory of Art», Studi Francesi [Online], 162 (LIV | III) | 2010, online dal 30 novembre 2015, consultato il 07 janvier 2021. URL: http://journals.openedition.org/studifrancesi/6426 ; DOI: https://doi.org/10.4000/studifrancesi.6426

Questo documento è stato generato automaticamente il 7 janvier 2021.

\section{(c) (i) $\odot$}

Studi Francesi è distribuita con Licenza Creative Commons Attribuzione - Non commerciale - Non opere derivate 4.0 Internazionale. 


\title{
Derek Allan, Art and the Human
} Adventure. André Malraux's Theory of Art

\author{
Riccardo Benedettini
}

\section{NOTIZIA}

DEREK ALLAN, Art and the Human Adventure. André Malraux's Theory of Art, Amsterdam-New York, Rodopi, 2009 («Faux Titre», 341), pp. 340.

1 Questo libro costituisce uno studio dei lavori di Malraux sulla teoria dell'arte: l'A., muovendo da alcune idee già pubblicate in saggi su rivista, si concentra principalmente su Les Voix du silence e La Métamorphose des dieux, considerati i testi principali dello scrittore sull'argomento. Già nella Introduction (pp.15-30), Allan mette in luce «the human importance of art» (p.20) e mostra che per Malraux «the significance of art is intimately connected to questions about the significance of man» (p. 20). La tesi è suffragata dall'analisi delle opere (quei libri sull'arte spesso dimenticati dalla critica accademica a favore dei romanzi) e si fonda su una base di ricerca che vaglia i più autorevoli pareri critici, come si deduce anche dalla Bibliography (pp.313-329) e dall'Index (pp. 331-340) che chiudono il volume. Per meglio definire i caratteri di questa lecture, l'A. non trascura di riprendere in esame la vita di Malraux, secondo un procedimento ormai tradizionale che segue l'influenza della persona (nella fattispecie il comunista, l'esistenzialista, il neofascista e il cattolico Malraux) sulla creazione.

2 I primi due capitoli, The Years before 1934 (pp. 31-46) e The Human Adventure (pp. 47-77), ruotano intorno al 1934, anno che segna, secondo l'A., un momento cruciale nell'evoluzione del pensiero di Malraux. È il confronto degli interrogativi «What is man?» e «What is art?» (p. 46), come la definizione di una nuova idea di «human life» (p.50), a guidare la presente ricerca. Per una prima risposta sulla natura della creazione artistica, Allan sostiene che l'arte è in grado di generare un «altro mondo», 
appunto Art: A Rival World (pp. 79-94); il risultato di questa differenza, the world created by art is unified (p. 80), è indagato in Art and Creation (pp. 95-129), dove l'A. mette in luce il senso metafisico che Malraux attribuiva all'arte. Su questi presupposti si basa The Emergence and Transformation of "Art" (pp.131-192), lungo capitolo riguardante historical developments vital to Malraux's thinking» (p.131), aspetti utili per comprendere la natura temporale dell'arte, "metamorfosi" valutata in Art and Time (pp. 193-229). Gli ultimi tre capitoli, The First Universal World of Art (pp. 231-274), The Anti-Arts (pp. 275-286) e Art, History, and the Human Adventure (pp. 287-296), muovono dall'interesse di Malraux verso le altre culture, per esaminare l'abbandono al puro assouvissement testimoniato da quelle stesse (anti)arti che generano «a tragic humanism» (p.296). Allan mette dunque in rilievo come Malraux abbia costruito un'estetica dell'arte tutta sua, ricorrendo a «the evocative powers of language» (p. 297) e alla definizione di una «relationship between art and time» (p.301), come leggiamo nella Conclusion (pp. 297-311). 